\title{
Two new hexacoordinated coordination polymers of cadmium(II) containing bridging units only: Syntheses, structures and molecular properties
}

\author{
DIPU SUTRADHAR ${ }^{\mathrm{a}}$, HABIBAR CHOWDHURY $^{\mathrm{b}, *}$, SUSHOVAN KONER $^{\mathrm{a}}$, SUBHASIS ROY $^{\mathrm{a}}$ \\ and BARINDRA KUMAR GHOSH ${ }^{\mathrm{a}, *}$ \\ a Department of Chemistry, The University of Burdwan, Burdwan, West Bengal, 713 104, India \\ ${ }^{b}$ Department of Chemistry, Kabi Nazrul College, Murarai, Birbhum, West Bengal, 731 219, India \\ e-mail: habibar_hs@yahoo.co.in; barin_1@yahoo.co.uk
}

MS received 15 May 2016; revised 30 July 2016; accepted 3 August 2016

\begin{abstract}
The syntheses, characterizations and structures of a neutral 2D coordination polymer $\left[\mathrm{Cd}(\text { bnzd })(\mathrm{NCS})_{2}\right]_{\mathrm{n}} \quad(\mathbf{1})$ and a polycationic $3 \mathrm{D}$ coordination polymer isolated as perchlorate salt $\left[\mathrm{Cd}(\text { bnzd })_{3}\right]_{\mathrm{n}}\left(\mathrm{ClO}_{4}\right)_{2 \mathrm{n}}(\mathbf{2})($ bnzd $=$ benzidine $)$ are described. X-ray structural analyses reveal that each hexacoordinated cadmium(II) center in $\mathbf{1}$ adopts a distorted octahedral geometry with a $\mathrm{CdN}_{4} \mathrm{~S}_{2}$ chromophore bound by two $\mathrm{N}$ atoms of two different bnzd units and two $\mathrm{N}$ and two $\mathrm{S}$ atoms of symmetric doubly bridged end-toend $\mathrm{NCS}^{-}$units extended in a 2D sheet. Six N atoms of six different bridged bnzd units are bonded to each cadmium(II) in 2 in a non-ended fashion affording a 3D network structure. In the crystalline state, each 2D sheet structure in $\mathbf{1}$ is further stabilized by $\pi \cdots \pi$ interaction which in turn affords a 3D network structure through multiple intermolecular $\mathrm{N}-\mathrm{H} \cdots \mathrm{S}$ hydrogen bonds. On the other hand, the 3D network structure in $\mathbf{2}$ is stabilized by weak intermolecular $\mathrm{N}-\mathrm{H} \cdots \mathrm{O}$ hydrogen bonds and $\mathrm{C}-\mathrm{H} \cdots \pi$ interactions. Bnzd, $\mathbf{1}$ and $\mathbf{2}$ display intraligand ${ }^{1}\left(\pi-\pi^{*}\right)$ fluorescence in DMF solution at room temperature.
\end{abstract}

Keywords. Cadmium(II); coordination polymers; benzidine; thiocyanate; X-ray structures; luminescence.

\section{Introduction}

The isolation of coordination polymers ${ }^{1}$ and supramolecular frameworks ${ }^{2}$ based upon strong covalent bonds ${ }^{3}$ and weak non-covalent forces ${ }^{4}$ is an area of current interest due to fabrication of new functional materials ${ }^{5-12}$ such as catalysts, ${ }^{5}$ magnetic materials, ${ }^{6}$ conducting materials, ${ }^{7}$ porous materials, ${ }^{8}$ luminous materials, ${ }^{9}$ nonlinear optical materials, ${ }^{10}$ chemical sensors ${ }^{11}$ and for molecular recognition. ${ }^{12}$ Judicious choice ${ }^{13}$ of suitable organic ligands with different denticities, polyatomic bridges with multiple connectors and metal templates gives rise to a diverse range of molecular and crystalline architectures. ${ }^{14,15}$ One-pot synthesis ${ }^{16}$ using the building units is an efficient approach to afford such metalorganic frameworks (MOFs). ${ }^{17}$ Thiocyanate ${ }^{18-20}$ has attracted much attention since it results in interesting extended architectures and related properties in metal bound states. Recently, we are active ${ }^{21-23}$ in the preparation of functional MOFs through variation of ligand frameworks and metal coordination environments. Polynuclear cadmium(II) compounds ${ }^{23-25}$ have received much attention due to electronic and optoelectronic

*For correspondence properties. ${ }^{26,27}$ Coordination chemistry of benzidine (bnzd, Scheme 1) is relatively less explored. ${ }^{28,29}$ This work stems from our interest to isolate coordination polymers and polymer-based supramolecular entities with photoluminescent behaviour. In the present endeavor, we have isolated and X-ray crystallographically characterized two new polynuclear cadmium(II) compounds of the composition $\left[\mathrm{Cd}(\text { bnzd })(\mathrm{NCS})_{2}\right]_{\mathrm{n}}(\mathbf{1})$ and $\left[\mathrm{Cd}(\text { bnzd })_{3}\right]_{\mathrm{n}}\left(\mathrm{ClO}_{4}\right)_{2 \mathrm{n}}$ (2) through use of the $4 \mathrm{~d}$ member Group 12 metal ion, cadmium(II), in combination with inorganic $\left(\mathrm{NCS}^{-}\right)$and organic (bnzd) bridging ligands.

\section{Experimental}

\subsection{Materials}

High purity benzidine (SRL, India), ammonium thiocyanate (E. Merck, India), cadmium(II) acetate dihydrate (SRL, India) were purchased and used as received. Cadmium perchlorate hexahydrate was prepared by treatment of cadmium carbonate (E. Merck, India) with perchloric acid (E. Merck, India) followed by slow evaporation on steam-bath, filtration through a fine glass-frit, and preservation in a desiccator containing 


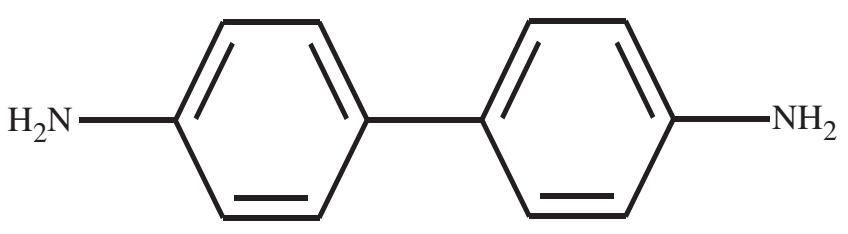

(bnzd)

Scheme 1. Framework of benzidine.

concentrated sulfuric acid (E. Merck, India) for subsequent use. All other chemicals and solvents used were AR grade. The synthetic reactions and work-up were done in open air at room temperature.

\subsection{Physical measurements}

Elemental analyses $(\mathrm{C}, \mathrm{H}$ and $\mathrm{N})$ were performed on a Perkin-Elmer $2400 \mathrm{CHNS} / \mathrm{O}$ elemental analyzer. IR spectra ( $\mathrm{KBr}$ discs, 4000-400 $\mathrm{cm}^{-1}$ ) were recorded using a Perkin-Elmer FTIR model RX1 spectrometer. Thermal studies were made with a Perkin-Elmer Diamond TG/DTA analyzer heated from $30-800^{\circ} \mathrm{C}$ under nitrogen atmosphere. Ground state absorptions were measured with a Jasco model V-530 UV-Vis spectrophotometer. Fluorescence measurements were done using a Hitachi Fluorescence Spectroflurimeter F-4500.

\subsection{Syntheses of the complexes}

2.3a $\quad\left[C d(b n z d)(N C S)_{2}\right]_{n}(1): \quad B n z d(0.184 \mathrm{~g}, 1 \mathrm{mmol})$ in methanol-acetonitrile $(9: 1)$ mixture $(20 \mathrm{~mL})$ was added slowly to a $\mathrm{Cd}(\mathrm{OAc})_{2} \cdot 2 \mathrm{H}_{2} \mathrm{O}(0.266 \mathrm{~g}, 1 \mathrm{mmol})$ solution in methanol $(10 \mathrm{~mL}) . \mathrm{NH}_{4} \mathrm{NCS}(0.152 \mathrm{~g}$, $2 \mathrm{mmol})$ in methanol $(10 \mathrm{~mL})$ was added dropwise to this solution mixture. After filtration through a fine glass frit, the supernatant yellowish-brown solution was kept in air for slow evaporation. Yellowish-brown crystals of $\mathbf{1}$ that deposited within a couple of days were collected by filtration and dried in vacuo over silica gel indicator. Yield: $0.289 \mathrm{~g}(70 \%)$. Anal. Calc. for $\mathrm{C}_{14} \mathrm{H}_{12} \mathrm{CdN}_{4} \mathrm{~S}_{2}$ (1): C, 40.7; H, 2.9; N, 13.6\%. Found: C, 40.9; H, 2.9; N, 13.7\%. IR (KBr, cm $\left.{ }^{-1}\right): v(\mathrm{~N}-\mathrm{H}) 3325$, 3244, 3147; v(C-H) 2914, 2856; $v(\mathrm{~N}=\mathrm{C}=\mathrm{S}) 2114$; $v(\mathrm{C}-\mathrm{S}) \quad 810 ; v(\mathrm{C}=\mathrm{N}) \quad 1612 ; v(\mathrm{C}=\mathrm{C})$ 1585. UV-Vis $\left(\lambda_{\max } / \mathrm{nm}\right): 297$.

$2.3 \mathrm{~b} \quad\left[\mathrm{Cd}(\mathrm{bnzd})_{3}\right]_{n}\left(\mathrm{ClO}_{4}\right)_{2 n}(2): \quad \mathrm{Cd}\left(\mathrm{ClO}_{4}\right)_{2} \cdot 6 \mathrm{H}_{2} \mathrm{O}$ $(0.419 \mathrm{~g}, 1 \mathrm{mmol})$ in methanol $(10 \mathrm{~mL})$ was added slowly to a solution of bnzd $(0.553 \mathrm{~g}, 3 \mathrm{mmol})$ in methanol-acetonitrile $(3: 1)$ mixture $(20 \mathrm{~mL})$. After filtration through a fine glass frit, the supernatant yellowish-brown solution was kept in air for slow evaporation. Brown crystals of $\mathbf{2}$ that deposited within a week were collected by filtration and dried in vacuo over silica gel indicator. Yield: $0.605 \mathrm{~g}(70 \%)$. Anal. Calc. for $\mathrm{C}_{36} \mathrm{H}_{36} \mathrm{CdCl}_{2} \mathrm{~N}_{6} \mathrm{O}_{8}$ (2): C, 50.0; H, 4.2; N, 9.7\%. Found: C, 50.2; H, 4.3; N, 9.8\%. IR $\left(\mathrm{KBr}, \mathrm{cm}^{-1}\right)$ : $v(\mathrm{~N}-\mathrm{H}) 3321,3241,3151$; $v(\mathrm{C}-\mathrm{H}) 2965,2920 ; v(\mathrm{C}=\mathrm{C})$ $1578 ; v_{\text {as }}(\mathrm{C}-\mathrm{N}) 1344,1324 ; v_{\mathrm{s}}(\mathrm{C}-\mathrm{N}) \quad 916 ; v\left(\mathrm{ClO}_{4}\right)$ 1104, 624. UV-Vis $\left(\lambda_{\max } / \mathrm{nm}\right): 296$.

\section{$2.4 \quad X$-ray crystallography}

Diffraction data of the single crystals of $\mathbf{1}$ and $\mathbf{2}$ were collected at $296 \mathrm{~K}$ on a Bruker SMART APEX II CCD area-detector diffractometer using graphite monochromated Mo-K $\alpha$ radiation $(0.71073 \AA)$. The unit cell parameters were obtained from SAINT ${ }^{30}$ and absorption corrections were performed with SADABS. ${ }^{31}$ The structures were solved by direct methods and refined by full-matrix least-squares method based on $|F|^{2}$ using SHELXL-97. All non-hydrogen atoms were refined with anisotropic displacement parameters. The $\mathrm{H}$ atoms were placed in calculated positions after checking their positions in the difference map. All calculations were carried out using SHELXL-97, SHELXTL, ${ }^{32}$ PLATON, ${ }^{33}$ Diamond $^{34}$ and Mercury $3.3^{35}$ programs. A summary of the crystallographic data and structure determination parameters for both complexes is given in Table 1.

\section{Results and Discussion}

\subsection{Synthesis and formulation}

One-pot syntheses of the building components in appropriate molar ratios (1:1:2 for $\mathbf{1}$ and $1: 3$ for 2 ) in methanol-acetonitrile solvent mixture at room temperature afforded a hexacoordinated 2D coordination polymer $\left[\mathrm{Cd}(\text { bnzd })(\mathrm{NCS})_{2}\right]_{\mathrm{n}}$ (1) and a 3D coordination polymer $\left[\mathrm{Cd}(\text { bnzd })_{3}\right]_{\mathrm{n}}\left(\mathrm{ClO}_{4}\right)_{2 \mathrm{n}}(\mathbf{2})$. The reactions were reproducible, as were evident from repetitive microanalytical and spectral results. The reproducibility reflects an inherent tendency towards the formation of $\mathbf{1}$ and $\mathbf{2}$. The reactions are summarized in Eqs. 1 and 2:

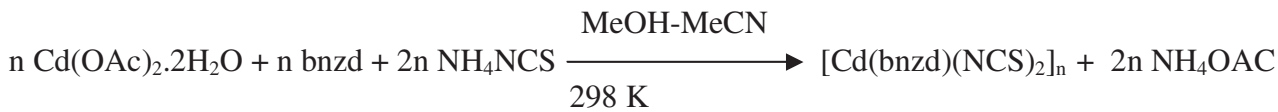

$$
\begin{aligned}
& \mathrm{n} \mathrm{Cd}\left(\mathrm{ClO}_{4}\right)_{2} \cdot 6 \mathrm{H}_{2} \mathrm{O}+3 \mathrm{n} \text { bnzd } \stackrel{\mathrm{MeOH}-\mathrm{MeCN}}{\longrightarrow}\left[\mathrm{Cd}(\mathrm{bnzd})_{3}\right]_{\mathrm{n}}\left(\mathrm{ClO}_{4}\right)_{2 \mathrm{n}}+6 \mathrm{n} \mathrm{H}_{2} \mathrm{O}
\end{aligned}
$$


Table 1. Crystallographic data for $\mathbf{1}$ and $\mathbf{2}$.

\begin{tabular}{|c|c|c|}
\hline Compound & 1 & 2 \\
\hline Chemical formula & $\mathrm{C}_{14} \mathrm{H}_{12} \mathrm{CdN}_{4} \mathrm{~S}_{2}$ & $\mathrm{C}_{36} \mathrm{H}_{36} \mathrm{CdCl}_{2} \mathrm{~N}_{6} \mathrm{O}_{8}$ \\
\hline Formula mass & 412.83 & 864.01 \\
\hline Crystal system & Triclinic & Rhombohedral \\
\hline Space group & P-1 & $\mathrm{R}-3 \mathrm{c}$ \\
\hline$a / \AA$ & $6.0444(4)$ & $9.5015(3)$ \\
\hline$b / \AA$ & $6.5440(5)$ & $9.5015(3)$ \\
\hline$c / \AA$ & $10.4117(5)$ & $65.063(3)$ \\
\hline$\alpha^{0}$ & $106.940(4)$ & 90 \\
\hline$\beta^{\circ}$ & $95.623(4)$ & 90 \\
\hline$\gamma^{0}$ & $97.824(5)$ & 120 \\
\hline$V / \AA^{3}$ & $386.15(4)$ & $5086.9(3)$ \\
\hline$\lambda / \AA$ & 0.71073 & 0.71073 \\
\hline$\rho_{\text {calcd }} / \mathrm{g} \mathrm{cm}^{-3}$ & 1.775 & 1.692 \\
\hline $\mathrm{Z}$ & 1 & 6 \\
\hline $\mathrm{T} / \mathrm{K}$ & $296(2)$ & $296(2)$ \\
\hline$\mu\left(\mathrm{mm}^{-1}\right)$ & 1.681 & 0.867 \\
\hline$F(000)$ & 204 & 2640 \\
\hline Crystal size $\left(\mathrm{mm}^{3}\right)$ & $0.12 \times 0.12 \times 0.10$ & $0.11 \times 0.15 \times 0.19$ \\
\hline$\theta$ ranges $\left(^{\circ}\right)$ & 3.304 to 24.643 & 1.88 to 28.49 \\
\hline$h / k / l$ & $-7,5 /-7,4 /-12,12$ & $-12,9 /-10,12 /-86,65$ \\
\hline Reflections collected & 1644 & 8867 \\
\hline Independent reflections & 1232 & 1439 \\
\hline Data/restraints/parameters & $1232 / 23 / 97$ & $1439 / 0 / 81$ \\
\hline $\mathrm{R}_{\text {int }}$ & 0.018 & 0.023 \\
\hline Final R1 values $[I>2 \sigma(I)]$ & 0.0345 & 0.0261 \\
\hline Final $w \mathrm{R}\left(\mathrm{F}^{2}\right)$ values $[I>2 \sigma(I)]$ & 0.0746 & 0.0952 \\
\hline Final R1 values (all data) & 0.0385 & 0.0348 \\
\hline Final $w R\left(F^{2}\right)$ values (all data) & 0.0772 & 0.1149 \\
\hline Goodness of fit on $\mathrm{F}^{2}$ & 1.017 & 0.942 \\
\hline Largest peak and hole $\left(\mathrm{e}^{-3}\right)$ & 0.359 and -0.466 & 0.621 and -0.717 \\
\hline
\end{tabular}

The air-stable and moisture-insensitive compounds $\mathbf{1}$ and $\mathbf{2}$ are insoluble in methanol, ethanol, dichloromethane and acetonitrile but moderately soluble in warm dimethylformamide.

\subsection{Spectroscopic features}

In IR spectra of $\mathbf{1}$ and $\mathbf{2}$, three peaks at $\sim 3320, \sim 3240$ and $\sim 3150 \mathrm{~cm}^{-1}$ are observed assignable to $v(\mathrm{NH})$ stretching vibrations of the $-\mathrm{NH}_{2}$ groups of bnzd. ${ }^{23 \mathrm{a}}$ Complex 1 shows an intense peak at $2114 \mathrm{~cm}^{-1}$ corresponding to $v(\mathrm{NCS})$. In $2, v\left(\mathrm{ClO}_{4}\right)$ stretches are found at 1104 and $624 \mathrm{~cm}^{-1}$. X-ray study corroborates this hypothesis and defines the molecular structure and crystalline architecture. The electronic spectra of the complexes $\mathbf{1}$ and $\mathbf{2}$ in DMF solution exhibit strong absorptions at $\sim 300 \mathrm{~nm}$ presumably due to ligandbased transition. ${ }^{36}$

\subsection{Molecular and crystal structures}

3.3a $\left[\mathrm{Cd}(\mathrm{bnzd})(\mathrm{NCS})_{2}\right]_{n}$ (1): An ORTEP diagram of the fundamental coordination unit of $\mathbf{1}$ with atom numbering scheme is shown in Figure 1. Selected bond distances $(\AA)$ and bond angles $\left(^{\circ}\right)$ are listed in Table 2 . Hydrogen bond and $\pi \cdots \pi$ interaction parameters are shown in Tables 3 and 4, respectively. The coordination polyhedron around each cadmium(II) center in the polymeric framework is best described as a distorted octahedron with a $\mathrm{CdN}_{4} \mathrm{~S}_{2}$ chromophore. Cadmium(II) is located on a crystallographic inversion center and one half of the monomeric unit is symmetrical to the other half. The coordination includes two amine $\mathrm{N}$ (N1 and $\mathrm{N} 1^{c}$ ) atoms of two different bnzd bridging units, two $\mathrm{N}\left(\mathrm{N} 2\right.$ and $\left.\mathrm{N} 2^{\mathrm{c}}\right)$ atoms and two $\mathrm{S}\left(\mathrm{S} 1^{\mathrm{a}}\right.$ and $\left.\mathrm{S} 1^{\mathrm{b}}\right)$ atoms of two thiocyanate units in symmetric doubly bridged end-to-end fashion [symmetry codes: ${ }^{\mathrm{a}} 1+\mathrm{x}, \mathrm{y}, \mathrm{z}$; 


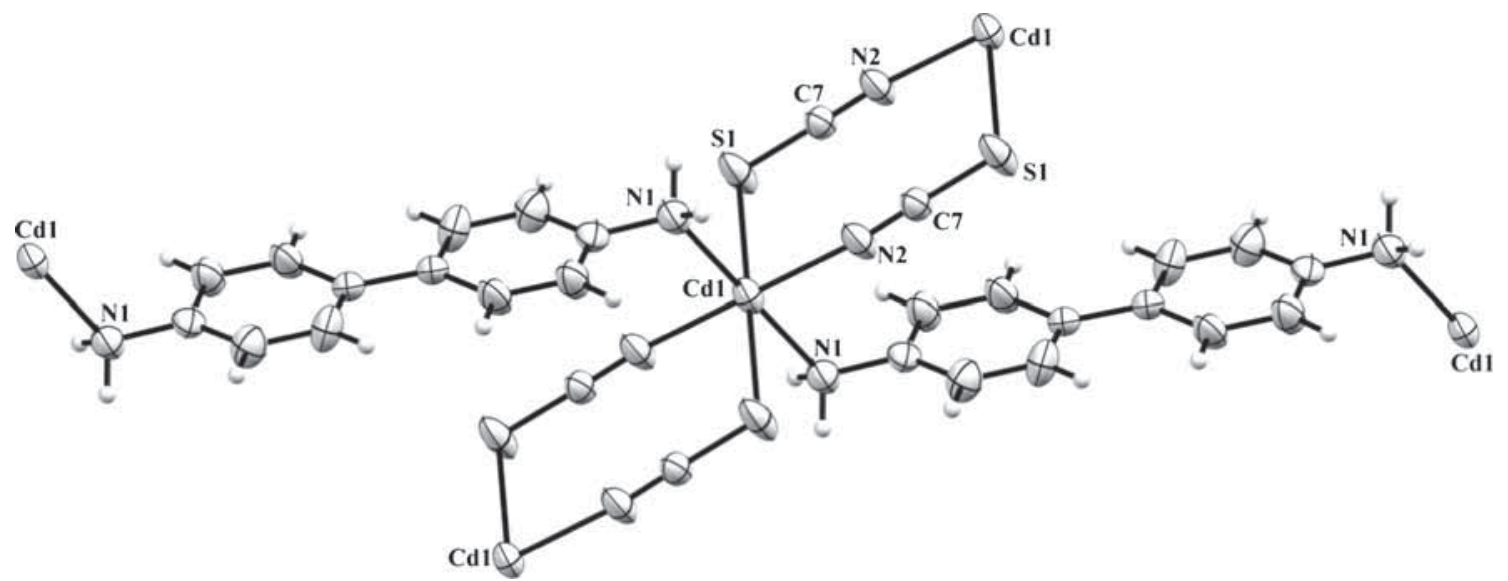

Figure 1. An ORTEP diagram of the fundamental coordination unit of 2D polymer 1 with $50 \%$ probability level of the ellipsoid.

Table 2. Selected bond distances $(\AA)$ and bond angles $\left(^{\circ}\right)$ for $\mathbf{1}$ and $\mathbf{2}$.

\begin{tabular}{|c|c|c|c|c|}
\hline \multirow{2}{*}{$\frac{\text { Parameters }}{\text { Bond distances }}$} & \multicolumn{2}{|c|}{1} & \multicolumn{2}{|c|}{2} \\
\hline & $\mathrm{Cd} 1-\mathrm{S} 1^{\mathrm{a}}$ & $2.7483(14)$ & Cd1-N1 & $2.4403(16)$ \\
\hline & $\mathrm{Cd} 1-\mathrm{S} 1^{\mathrm{b}}$ & $2.7483(14)$ & $\mathrm{Cd} 1-\mathrm{N} 1^{\mathrm{d}}$ & $2.4402(16)$ \\
\hline & Cd1-N1 & $2.346(4)$ & $\mathrm{Cd} 1-\mathrm{N} 1^{\mathrm{e}}$ & $2.4402(16)$ \\
\hline & $\mathrm{Cd} 1-\mathrm{N} 1^{\mathrm{c}}$ & $2.346(4)$ & $\mathrm{Cd} 1-\mathrm{N} 1^{\mathrm{f}}$ & $2.4402(16)$ \\
\hline & Cd1-N2 & $2.308(4)$ & $\mathrm{Cd} 1-\mathrm{N} 1^{\mathrm{g}}$ & $2.4402(16)$ \\
\hline & $\mathrm{Cd} 1-\mathrm{N} 2^{\mathrm{c}}$ & $2.308(4)$ & $\mathrm{Cd} 1-\mathrm{N} 1^{\mathrm{h}}$ & $2.4402(16)$ \\
\hline \multirow[t]{16}{*}{ Bond angles } & N1-Cd1-N2 & $86.56(14)$ & $\mathrm{N} 1-\mathrm{Cd} 1-\mathrm{N} 1^{\mathrm{d}}$ & $96.56(5)$ \\
\hline & $\mathrm{N} 1-\mathrm{Cd} 1-\mathrm{N} 1^{\mathrm{c}}$ & 180.00 & $\mathrm{~N} 1-\mathrm{Cd} 1-\mathrm{N} 1^{\mathrm{e}}$ & $96.56(5)$ \\
\hline & $\mathrm{N} 1-\mathrm{Cd} 1-\mathrm{N} 2^{\mathrm{c}}$ & $93.44(14)$ & $\mathrm{N} 1-\mathrm{Cd} 1-\mathrm{N} 1^{\mathrm{f}}$ & 180.0 \\
\hline & $\mathrm{N} 2-\mathrm{Cd} 1-\mathrm{N} 2^{\mathrm{c}}$ & 180.00 & $\mathrm{~N} 1-\mathrm{Cd} 1-\mathrm{N} 1^{\mathrm{g}}$ & $83.44(5)$ \\
\hline & $\mathrm{N} 1{ }^{\mathrm{c}}-\mathrm{Cd} 1-\mathrm{N} 2$ & $93.44(14)$ & $\mathrm{N} 1-\mathrm{Cd} 1-\mathrm{N} 1^{\mathrm{h}}$ & $83.44(5)$ \\
\hline & $\mathrm{N} 1^{\mathrm{c}}-\mathrm{Cd} 1-\mathrm{N} 2^{\mathrm{c}}$ & $86.56(14)$ & $\mathrm{N}^{\mathrm{d}}-\mathrm{Cd} 1-\mathrm{N} 1^{\mathrm{e}}$ & $96.56(5)$ \\
\hline & $\mathrm{S} 1^{\mathrm{a}}-\mathrm{Cd} 1-\mathrm{N} 1$ & $93.82(10)$ & $\mathrm{N} 1^{\mathrm{d}}-\mathrm{Cd} 1-\mathrm{N} 1^{\mathrm{f}}$ & $83.44(5)$ \\
\hline & $\mathrm{S} 1^{\mathrm{a}}-\mathrm{Cd} 1-\mathrm{N} 2$ & $88.76(11)$ & $\mathrm{N} 1^{\mathrm{d}}-\mathrm{Cd} 1-\mathrm{N} 1^{\mathrm{g}}$ & $180.00(6)$ \\
\hline & $\mathrm{S} 1^{\mathrm{a}}-\mathrm{Cd} 1-\mathrm{N} 1^{\mathrm{c}}$ & $86.18(10)$ & $\mathrm{N} 1^{\mathrm{d}}-\mathrm{Cd} 1-\mathrm{N} 1^{\mathrm{h}}$ & $83.44(5)$ \\
\hline & $\mathrm{S} 1^{\mathrm{a}}-\mathrm{Cd} 1-\mathrm{N} 2^{\mathrm{c}}$ & $91.24(11)$ & $\mathrm{N} 1^{\mathrm{e}}-\mathrm{Cd} 1-\mathrm{N} 1^{\mathrm{f}}$ & $83.44(5)$ \\
\hline & $\mathrm{S} 1^{\mathrm{a}}-\mathrm{Cd} 1-\mathrm{S} 1^{\mathrm{b}}$ & 180.00 & $\mathrm{~N} 1^{\mathrm{e}}-\mathrm{Cd} 1-\mathrm{N} 1^{\mathrm{g}}$ & $83.44(5)$ \\
\hline & $\mathrm{S} 1^{\mathrm{b}}-\mathrm{Cd} 1-\mathrm{N} 1$ & $86.18(10)$ & $\mathrm{N} 1^{\mathrm{e}}-\mathrm{Cd} 1-\mathrm{N} 1^{\mathrm{h}}$ & $180.00(8)$ \\
\hline & $\mathrm{S} 1^{\mathrm{b}}-\mathrm{Cd} 1-\mathrm{N} 2$ & $91.24(11)$ & $\mathrm{N} 1^{\mathrm{f}}-\mathrm{Cd} 1-\mathrm{N} 1^{\mathrm{g}}$ & $96.56(5)$ \\
\hline & $\mathrm{S} 1^{\mathrm{b}}-\mathrm{Cd} 1-\mathrm{N} 1^{\mathrm{c}}$ & $93.82(10)$ & $\mathrm{N} 1^{\mathrm{f}}-\mathrm{Cd} 1-\mathrm{N} 1^{\mathrm{h}}$ & $96.56(5)$ \\
\hline & $\mathrm{S} 1^{\mathrm{b}}-\mathrm{Cd} 1-\mathrm{N} 2^{\mathrm{c}}$ & $88.76(11)$ & $\mathrm{N} 1^{\mathrm{g}}-\mathrm{Cd} 1-\mathrm{N} 1^{\mathrm{h}}$ & $96.56(5)$ \\
\hline & $\mathrm{S} 1-\mathrm{C} 7-\mathrm{N} 2$ & $178.5(4)$ & & \\
\hline
\end{tabular}

Symmetry code: ${ }^{\mathrm{a}} 1+\mathrm{x}, \mathrm{y}, \mathrm{z} ;{ }^{\mathrm{b}} 1-\mathrm{x}, 1-\mathrm{y}, 2-\mathrm{z} ;{ }^{\mathrm{c}} 2-\mathrm{x}, 1-\mathrm{y}, 2-\mathrm{z} ;{ }^{\mathrm{d}} 2-\mathrm{y}, 1+\mathrm{x}-\mathrm{y}, \mathrm{z} ;{ }^{\mathrm{e}} 1-\mathrm{x}+\mathrm{y}, 2-\mathrm{x}, \mathrm{z} ;$

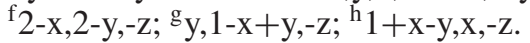

Table 3. Hydrogen bond and $\mathrm{C}-\mathrm{H} \cdots \pi$ interaction parameters for $\mathbf{1}$ and $\mathbf{2}$.

\begin{tabular}{|c|c|c|c|c|c|}
\hline \multirow{3}{*}{$\frac{\text { Compound }}{1}$} & \multicolumn{5}{|c|}{ Hydrogen bond $\left(\AA,^{\circ}\right)$} \\
\hline & $\mathrm{D}-\mathrm{H} \cdots \mathrm{A}$ & D-H & $\mathrm{H} \cdots \mathrm{A}$ & D $\cdots A$ & $\mathrm{D}-\mathrm{H} \cdots \mathrm{A}$ \\
\hline & N1-H1A $\cdots$ S1 & 0.9700 & 2.5700 & $3.523(4)$ & 169.00 \\
\hline \multirow[t]{4}{*}{2} & \multicolumn{5}{|c|}{ Hydrogen bond and C-H $\cdots \pi$ interaction $\left(\AA,^{\circ}\right)$} \\
\hline & $\mathrm{N} 1-\mathrm{H} 1 \mathrm{~A} \cdots \mathrm{O} 1$ & 0.9000 & 2.4600 & $3.235(4)$ & 144.00 \\
\hline & $\mathrm{N} 1-\mathrm{H} 1 \mathrm{~A} \cdot \cdots \mathrm{O} 1^{\mathrm{h}}$ & 0.9000 & 2.3300 & $3.217(3)$ & 167.00 \\
\hline & $\mathrm{C} 3-\mathrm{H} 3 \cdots \mathrm{Cg}(1)$ & 0.9300 & 2.8300 & $3.588(18)$ & 139.00 \\
\hline
\end{tabular}

Symmetry code: ${ }^{\mathrm{h}} 1+\mathrm{x}-\mathrm{y}, \mathrm{x}, \mathrm{z} ; \mathrm{Cg}(1)=\mathrm{C}(1) \rightarrow \mathrm{C}(2) \rightarrow \mathrm{C}(3) \rightarrow \mathrm{C}(4) \rightarrow \mathrm{C}(5) \rightarrow \mathrm{C}(6)$. 
Table 4. $\pi \cdots \pi$ interaction parameter for $\mathbf{1}$.

$$
\pi \cdots \pi \text { interactions }\left(\AA,^{\circ}\right)
$$

\begin{tabular}{lcccc}
\hline Ring-ring & Cg-Cg distance & Dihedral angle $(\mathrm{i}, \mathrm{j})$ & Perpendicular distances between baricenters (i, j) & Slippage \\
$\mathrm{Cg}(1)-\mathrm{Cg}(1)^{\mathrm{i}}$ & $3.685(3)$ & 0.00 & $3.407(2)$ & 1.404
\end{tabular}

Symmetry code: ${ }^{i} 2-\mathrm{x},-\mathrm{y}, 1-\mathrm{z} ; \mathrm{Cg}(1)=\mathrm{C}(1) \rightarrow \mathrm{C}(2) \rightarrow \mathrm{C}(3) \rightarrow \mathrm{C}(4) \rightarrow \mathrm{C}(5) \rightarrow \mathrm{C}(6)$.

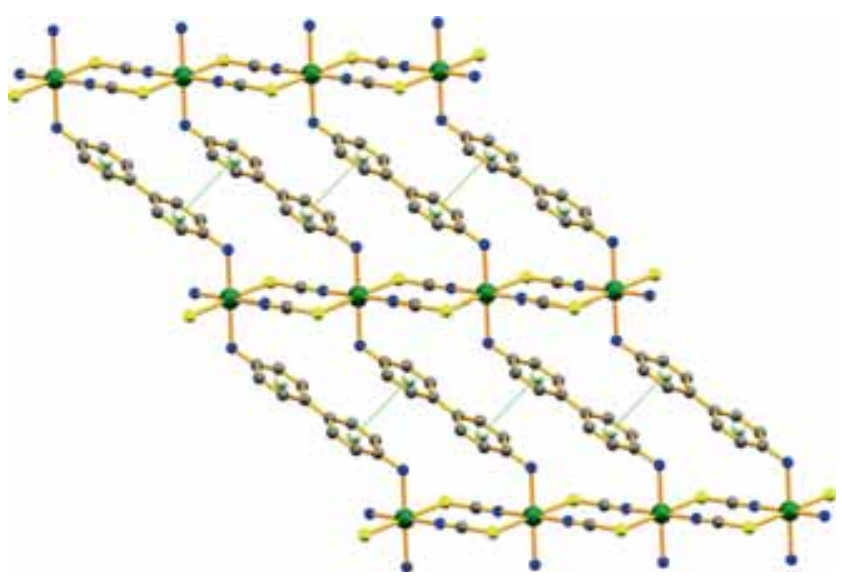

Figure 2. 2D sheet structure in 1 stabilized by $\pi \cdots \pi$ interaction parallel to the bc-plane.

$\left.{ }^{\mathrm{b}} 1-\mathrm{x}, 1-\mathrm{y}, 2-\mathrm{z} ;{ }^{\mathrm{c}} 2-\mathrm{x}, 1-\mathrm{y}, 2-\mathrm{z}\right]$. Two nitrile $\mathrm{N}\left(\mathrm{N} 2\right.$ and N2 $\left.{ }^{\mathrm{c}}\right)$ atoms of bnzd and two $\mathrm{S}\left(\mathrm{S} 1^{\mathrm{a}}\right.$ and $\left.\mathrm{S} 1^{\mathrm{b}}\right)$ atoms of two double $\mu_{1,3}$ bridged $\mathrm{NCS}^{-}$define the equatorial plane whereas two amine $\mathrm{N}\left(\mathrm{N} 1\right.$ and $\left.\mathrm{N} 1^{\mathrm{c}}\right)$ atoms of two different bnzd bridges occupy the axial positions. The axial Cd-N distance $[2.346 \AA$ ] is to some extent greater than the equatorial Cd-N distance [2.308 $\AA$ ] which is in line with the distorted coordination geometry. The sum of the equatorial bond angles $\left(91.24^{\circ}, 91.24^{\circ}, 88.76^{\circ}\right.$ and $88.76^{\circ}$ ) is exactly $360^{\circ}$ indicating all the equatorial $\mathrm{N}$ atoms along with $\mathrm{Cd} 1$ are in a least-squares plane. Double $\mu_{1,3} \mathrm{NCS}^{-}$bridges connect the neighboring cadmium(II) centers in the $2 \mathrm{D}$ polymer along b-axis forming eight-membered $\mathrm{Cd}-(\mathrm{NCS})_{2}$-Cd loops with a rectangular conformation. A net $(4,4)$ topology of the $2 \mathrm{D}$ polymer parallel to the $b c$ plane can be conceived by connecting each cadmium(II) center of $1 \mathrm{D}$ chain along b-axis formed by two double $\mu 1,3 \mathrm{NCS}^{-}$with binucleating, end-to-end bridging bnzd along c-axis. Cd $\cdots$ Cd separation across double $\mu 1,3 \mathrm{NCS}^{-}$bridge is shorter $(6.044 \AA)$ than that (13.083 $\AA$ ) through bnzd, as expected. This $2 \mathrm{D}$ sheet structure is further stabilized by $\pi \cdots \pi$ interactions (Figure 2). 2D polymeric units lying parallel to the bc plane are associated by weak intermolecular hydrogen bonds (N1-H1A ...S 1 , $2.57 \AA, 169^{\circ}$ ) involving the $\mathrm{S}$ atom (S1) of $\mathrm{NCS}^{-}$ and $\mathrm{H}$ atom (H1A) of amine $\mathrm{N}(\mathrm{N} 1)$ of bnzd in the successive polymeric sheets along the a-axis affording

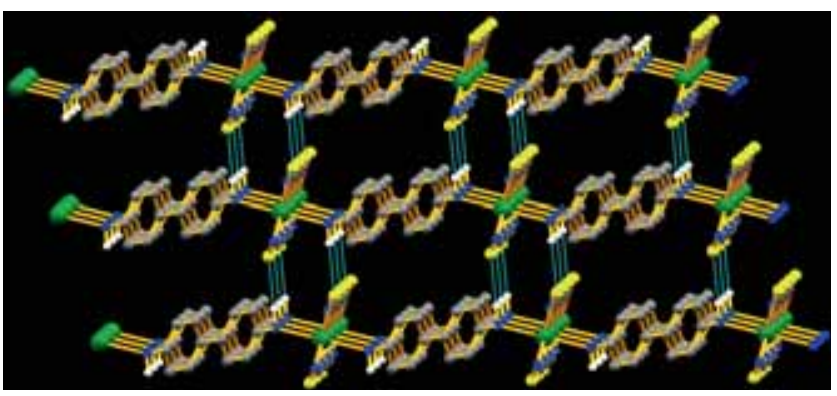

Figure 3. 3D network structure in $\mathbf{1}$ formed through intermolecular $\mathrm{N}-\mathrm{H} \cdots \mathrm{S}$ hydrogen bonds.

a 3D network structure (Figure 3). The specific orientation of the bnzd unit in a sheet towards the $\mathrm{NCS}^{-}$ of its adjacent sheet is responsible for the formation of such a superstructure through multiple non-covalent interactions.

3.3b $\left[\mathrm{Cd}(\mathrm{bnzd})_{3}\right]_{n}\left(\mathrm{ClO}_{4}\right)_{2 n}(2)$ : A perspective view of the fundamental unit with the atom labeling scheme of the coordination polymer 2 is shown in Figure 4. Selected bond distances $(\AA)$ and bond angles $\left({ }^{\circ}\right)$ may be found in Table 2 and hydrogen bond and C-H $\cdots \pi$ interaction parameters, in Table 3. In individual polycationic $\left[\mathrm{Cd}(\text { bnzd })_{3}\right]_{\mathrm{n}}^{2 \mathrm{n}+}$ species, the coordination environment around each cadmium(II) is a distorted octahedron with a $\mathrm{CdN}_{6}$ chromophore. The coordination includes six amine $\mathrm{N}$ atoms $\left(\mathrm{N} 1, \mathrm{~N} 1^{\mathrm{d}}, \mathrm{N} 1^{\mathrm{e}}, \mathrm{N}^{\mathrm{f}}, \mathrm{N} 1^{\mathrm{g}}\right.$ and $\mathrm{N} 1^{\mathrm{h}}$; symmetry codes: ${ }^{\mathrm{d}} 2-\mathrm{y}, 1+\mathrm{x}-\mathrm{y}, \mathrm{z} ;{ }^{\mathrm{e}} 1-\mathrm{x}+\mathrm{y}, 2-\mathrm{x}, \mathrm{z} ;{ }^{\mathrm{f}} 2-\mathrm{x}$, $2-y,-z ;{ }^{g} y, 1-x+y,-z$ and $\left.{ }^{\mathrm{h}}+\mathrm{x}-\mathrm{y}, \mathrm{x},-\mathrm{z}\right)$ of six different didentate bnzd bridges. The cisoid $\left[83.44(5)^{\circ}-\right.$ $\left.96.56(5)^{\circ}\right]$ and transoid $\left[180.00(8)^{\circ}\right]$ angles around each cadmium(II) center are in consonance with distortion from an idealized octahedron. The bridges are symmetric as is evident from similar $\mathrm{Cd}-\mathrm{N}$ distances [Cd1$\mathrm{N} 12$ 2.4413(17) $\AA$ ]. An increase in Cd-N(bnzd) distance from $1(2.346 \AA)$ to 2 (2.441 $\AA$ ) may presumably be due to steric crowding present in this binary coordination polymer arising from the steric interaction of ortho hydrogens of the six bnzd units around the metal(II) center. In the ternary complex $\mathbf{1}$, the presence of the didentate bridging ligand $\mathrm{NCS}^{-}$on the molecular plane and the housing of the two bnzd unit on axial position alleviates such steric crowding and thereby reducing 


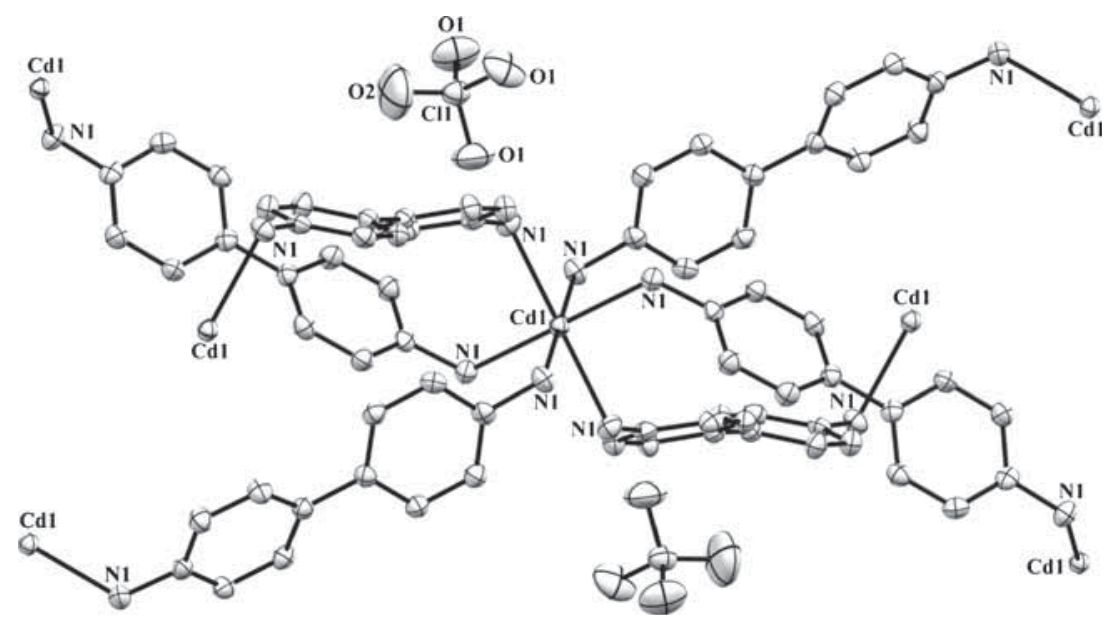

Figure 4. An ORTEP diagram of the fundamental coordination unit of 3D polymer 2 with 50\% probability level of the ellipsoid.

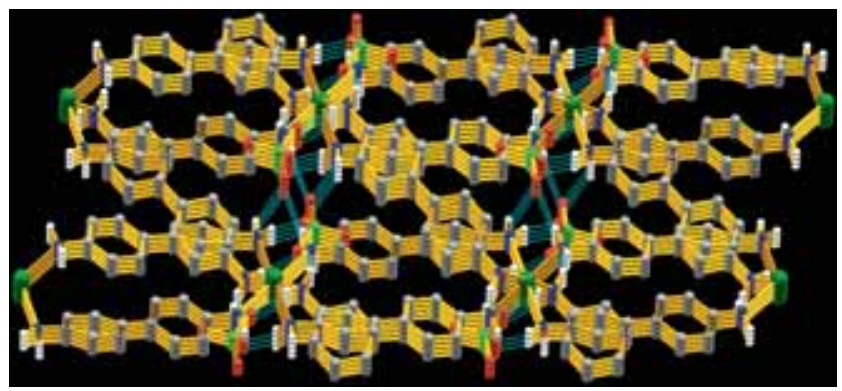

Figure 5. 3D network structure in 2 stabilized by intermolecular $\mathrm{N}-\mathrm{H}$... O hydrogen bonds.

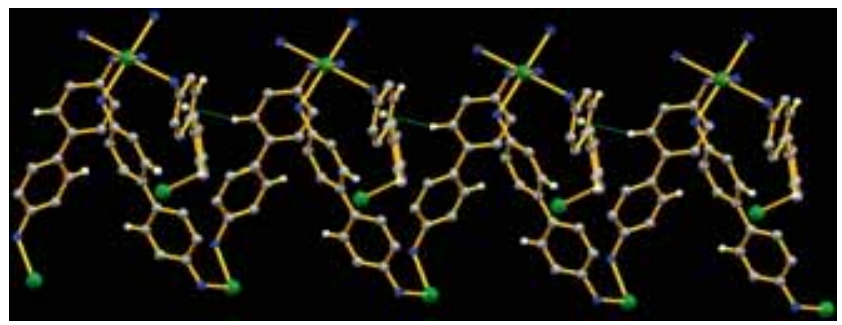

Figure 6. 3D network structure in $\mathbf{2}$ stabilized by $\mathrm{C}-\mathrm{H} \cdots \pi$ interactions.

the $\mathrm{Cd}-\mathrm{N}$ (bnzd) distance substantially and closer to Cd-N(thiocyanate) distance $(2.308 \AA)$. Each fundamental unit of cadmium(II) is connected with six different cadmium(II) centers through bnzd bridges in nonending fashion affording a 3D network structure. The $\mathrm{Cd} \cdot \mathrm{Cd}$ separation across the bnzd bridge is 12.153 $\AA$. In the crystalline state, the 3D network is stabilized by intermolecular H-bonds (N1-H1A...OO1 and $\mathrm{N} 1-\mathrm{H} 1 \mathrm{~B} \cdot \mathrm{O}$ - 1$)$ involving the $\mathrm{O}$ atom $(\mathrm{O} 1)$ of $\mathrm{ClO} 4-$ ion and $\mathrm{H}$ atoms (H1A and $\mathrm{H} 1 \mathrm{~B})$ of amine $\mathrm{N}$ (N1) of bnzd units (Figure 5) and $\mathrm{C}-\mathrm{H} \cdots \pi$ interactions $(\mathrm{C} 3-\mathrm{H} 3 \cdots \mathrm{Cg}(1))$ (Figure 6).

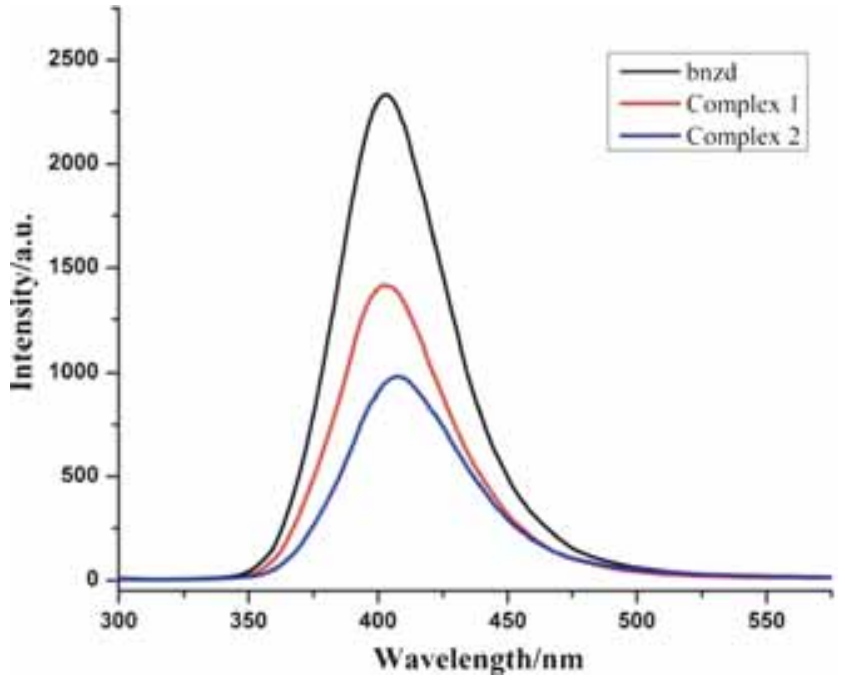

Figure 7. Fluorescence spectra of free bnzd, $\mathbf{1}$ and $\mathbf{2}$ in DMF solutions at $298 \mathrm{~K}$.

\subsection{Thermal studies}

To examine thermal stabilities of $\mathbf{1}$ and $\mathbf{2}$, thermogravimetric analyses (TG) were made between $30^{\circ} \mathrm{C}$ and $800^{\circ} \mathrm{C}$ in a static atmosphere of nitrogen. The TG curve (Figure S1) of 1 indicates that it is stable up to $214^{\circ} \mathrm{C}$ at which temperature decomposition commences and its decomposition takes place gradually in the temperature range $214-568^{\circ} \mathrm{C}$ corresponding to the weight loss (observed, $63.2 \%$ and calculated, $72.8 \%$ ) of two $\mathrm{NCS}^{-}$ ions and one bnzd unit per formula unit. The TG curve (Figure S2) of 2 shows that the compound is stable up to $210^{\circ} \mathrm{C}$ and its decomposition takes place gradually in the temperature range $210-540^{\circ} \mathrm{C}$ corresponding to the weight loss (observed, 83.2\% and expected, $87.0 \%$ ) of three bnzd units and two perchlorate ions per formula unit. 


\subsection{Fluorescence studies}

Light brown DMF solutions of free bnzd, 1 and $\mathbf{2}$ show strong absorption at 253, 297 and $296 \mathrm{~nm}$, respectively, presumably due to ligand-based transition. ${ }^{36}$ Upon photoexcitation at the corresponding absorption band in DMF solution, free bnzd exhibits a broad fluorescent emission centered at $402 \mathrm{~nm}$; the corresponding cadmium(II) complexes $\mathbf{1}$ and $\mathbf{2}$ show less intense photoluminescence ${ }^{37}$ with the main emission at the same position as that of free bnzd unit itself due to the intraligand ${ }^{1}\left(\pi-\pi^{*}\right)$ transition (Figure 7 ). The less intensity in case of these coordination compounds may be attributed to heavy ion effect.

\section{Conclusions}

In summary, two coordination polymers of cadmium(II) are isolated using bridging units only. The $2 \mathrm{D}$ polymer $\mathbf{1}$ is a neutral one with two types of bridging ligands and 3D polycationic polymer 2 contains one kind of bridging unit. The two coordination polymers with different metal-organic frameworks (MOFs) afford different crystalline architectures through varied multiple weak non-covalent forces. These are thermally stable and behave as luminous materials.

\section{Supplementary Information (SI)}

Crystallographic data for the structural analyses have been deposited with the Cambridge Crystallographic data center No. 1409173 (1) and 1409172 (2). Copy of this information can be obtained, free of charge from 'The Director, CCDC, 12 Union Road, Cambridge, CB2 1EZ, UK (fax: +44 1223 336033; e-mail: deposit@ccdc.cam.ac.uk or http://www.ccdc. cam.ac.uk)'. Thermal behavior of compounds $\mathbf{1}$ and $\mathbf{2}$ (Figures S1 and S2, respectively) are shown in Supplementray Information, available at www.ias.ac.in/ chemsci.

\section{Acknowledgements}

Financial support from the Council of Science and Industrial Research (CSIR), New Delhi, India is gratefully acknowledged by BKG. HC thanks to University Grant Commission (UGC), ERO for financial assistance [Project No. F. No. PSW-20/13-14 (ERO)].

\section{References}

1. (a) Hong M-C and Chen L 2009 In Design and Construction of Coordination Polymers (Hoboken, New Jersey: John Wiley); (b) Tao T, Lei Y-H, Peng Y-X, Wang Y,
Huang W, Chen Z-X and You XZ 2012 Cryst. Growth Des. 12 4580; (c) Yang L-Z, Fang R, Dou W, Kirillov A M, Xu C-L and Liu WS 2015 CrystEngComm 173117

2. (a) Lehn J-M 1995 In Supramolecular Chemistry: Concepts and Perspectives (Weinheim: VCH); (b) Steed J W and Atwood J L 2009 In Supramolecular Chemistry $2^{\text {nd }}$ edn. (New York: Wiley)

3. (a) Seidel S R and Stang P J 2002 Acc. Chem. Res. 35 972; (b) Steel P J 2005 Acc. Chem. Res. 38 243; (c) Neidig M L, Clark D L and Martin R L 2013 Coord. Chem. Rev. 257394

4. (a) Jeffrey G A 1997 In An introduction to hydrogen bonding (Oxford: Oxford University Press); (b) Nishio M, Hirota M and Umezawa Y 1998 In The $\mathrm{CH} / \pi$ interaction (New York: Wiley-VCH); (c) Tiekink E R T and Zukerman-Schpector J 2012 In The importance of Pi-interactions in Crystal Engineering: Frontiers in Crystal Engineering $1^{\text {st }}$ edn. (Chichester, UK: John Wiley); (d) Reedijk J 2013 Chem. Soc. Rev. 42 1776; (e) Desiraju G R, Ho P S, Kloo L, Legon A C, Marquardt R, Metrangolo P, Jaaskelainen P A S, Rissanen K and Haukka M 2015 CrystEngComm 171231

5. (a) B Cornils, W A Hermann, R Scholgl and C-H Wong (Eds.) 2000 In Catalysis from A to Z: A concise encyclopedia (New York: John Wiley); (b) Yoon M, Srirambalaji R and Kim K 2012 Chem. Rev. 112 1196; (c) Guo Z, Liu B, Zhang Q, Deng W, Wang Y and Yang Y 2014 Chem. Soc. Rev. 433480

6. (a) Kahn O 1993 In Molecular magnetism (New York: VCH); (b) J S Miller and M Drillon (Eds.) 2005 In Magnetism: Molecules to Materials V (Weinheim: Wiley-VCH); (c) Spaldin N A 2010 In Magnetic Materials: Fundamentals and Applications (New York: Cambridge University Press); (d) Benelli C and Gatteschi D 2015 In Introduction to Molecular Magnetism: From Transition Metals to Lanthanides (Weinheim, Germany: Wiley-VCH)

7. (a) Farraro J R and Williams J M 1987 In Introduction to Synthetic Electrical Conductors (New York: Academic Press); (b) Wallace G G, Teasdale P R, Spinks G M and Kane-Maguire L A P 2008 In Conductive Electroactive Polymers: Intelligent Polymer Systems 3rd edn. (Boca Raton (US): CRC Press); (c) Ramaswamy P, Wong N E and Shimizu G K H 2014 Chem. Soc. Rev. 435913

8. (a) Furukawa H, Gandara F, Zhang Y-B, Jiang J, Queen W L, Hudson M R and Yaghi O M 2014 J. Am. Chem. Soc. 136 4369; (b) Duan J, Higuchi M, Krishna R, Kiyonaga T, Tsutsumi Y, Sato Y, Kubota Y, Takata M and Kitagawa S 2014 Chem. Sci. 5 660; (c) He Y, Zhou W, Qian G and Chen B 2014 Chem. Soc. Rev. 435657

9. (a) Kitai A 2008 In Luminescent materials and applications (Chichester: John Wiley); (b) Yukihara E G and McKeever S W S 2011 In Optically Stimulated Luminescence: Fundamentals and Applications (Chichester: John Wiley); (c) Dou Z, Yu J, Cui Y, Yang Y, Wang Z, Yang D and Qian G 2014 J. Am. Chem. Soc. 1365527

10. (a) Chen X, Zhang G, Zeng H, Guo Q and She W 2015 In Advances in Nonlinear Optics (Germany: Walter de Gruyter GmbH); (b) Wang C, Zhang T and Lin W 2012 Chem. Rev. 112 1084; (c) Xu H, Chen R, Sun Q, Lai W, Su Q, Huang W and Liu X 2014 Chem. Soc. Rev. 433259 
11. (a) Kreno L E, Leong $\mathrm{K}$, Farha $\mathrm{O} \mathrm{K}$, Allendorf $\mathrm{M}$, Duyne R P V and Hupp J T 2012 Chem. Rev. 112 1105; (b) Liu Z F, Wu M F, Zheng F K, Wang S H, Zhang M J, Chen J, Xiao Y, Guo G C and Wu A Q 2013 CrystEngComm 15 7038; (c) Fenzl C, Hirsch T and Wolfbeis O S 2014 Angew. Chem. Int. Ed. 533318

12. (a) Joyce L A, Shabbir S H and Anslyn E V 2010 Chem. Soc. Rev. 39 3621; (b) Zheng B, Wang F, Dong S and Huang F 2012 Chem. Soc. Rev. 41 1621; (c) Mu B, Zhang J, McNicholas T P, Reuel N F, Kruss S and Strano M S 2014 Acc. Chem. Res. 47979

13. (a) Bencini A and Lippolis V 2010 Coord. Chem. Rev. 254 2096; (b) Cook T R, Zheng Y R and Stang P J 2013 Chem. Rev. 113 734; (c) Lin Z-J, Lu J, Hong M and Cao R 2014 Chem. Soc. Rev. 435867

14. (a) Novoa J J, Braga D and Addadi L 2007 In Engineering of crystalline materials properties: State of the art in modeling, design and applications (Netherlands: Springer Science \& Business Media); (b) Samora P and Cacialli F 2014 In Functional supramolecular architectures: For organic electronics and nanotechnology (Weinheim: John Wiley)

15. (a) Zaworotko M J 2007 Cryst. Growth Des. 7 4; (b) Zhang L, Zheng J-D, Chen Y-T, Zheng S-R, Fan J and Zhang W-G 2015 CrystEngComm 175538

16. (a) Chakrabarty R, Mukherjee P S and Stang P J 2011 Chem. Rev. 111 6810; (b) Ward M D and Raithby P R 2013 Chem. Soc. Rev. 42 1619; (c) Carnes M E, Collins M S and Johnson D W 2014 Chem. Soc. Rev. 431825

17. (a) Macgillivray L R (Ed.) 2010 In Metal-organic frameworks: design and application (Hoboken, New Jersey: John Wiley); (b) Coronado E and Espallargas G M 2013 Chem. Soc. Rev. 42 1525; (c) Zheng Y-Z, Zheng Z and Chen X-M 2014 Coord. Chem. Rev. 2581

18. (a) Golub A M, Kohler H and Skopenko V V (Eds) 1986 In Chemistry of Pseudohalides, (Amsterdam: Elsevier); (b) Malecki J G, Gron T and Duba H 2012 Polyhedron 36 56; (c) Boeckmann J, Evers N and Nather C 2012 CrystEngComm 141094

19. (a) Machura B, Switlicka A, Mrozinski J, Kalinska B and Kruszynski R 2013 Polyhedron 52 1276; (b) Li H-H, You Z-L, Zhang C-L, Yang M, Gao L-N and Wang L 2013 Inorg. Chem. Comm. 29118

20. (a) Ma Q, Zhu M, Yuan C, Feng S, Lu L and Wang Q 2010 Cryst. Growth Des. 10 1706; (b) Bikas R, Hosseini-Monfared H, Siczek M, Gutierrez A, Krawczyk M S and Lis T 2014 Polyhedron 67396

21. (a) Bhar K, Khan S, Costa J S, Ribas J, Roubeau O, Mitra P and Ghosh B K 2012 Angew. Chem. Int. Ed. 51 2142; (b) Choubey S, Bhar K, Chattopadhyay S, Hazra A, Maji T K, Ribas J and Ghosh B K 2012 Dalton Trans. 4111551

22. (a) Kundu S, Roy S, Bhar K, Ghosh R, Lin C-H, Ribas J and Ghosh B K 2013 J. Chem. Sci. 125 723; (b) Kundu S, Roy S, Bhar K, Ghosh R, Lin C-H, Ribas J and Ghosh B K 2013 J. Mol. Struct. 103878

23. (a) Chattopadhyay S, Bhar K, Das S, Khan S, Mitra P, Ribas J and Ghosh B K 2012 Polyhedron 39 48; (b) Roy S, Choubey S, Khan K, Bhar K, Ribas J and Ghosh B K 2014 J. Mol. Struct. 106154

24. (a) Deng H, Qiu Y-C, Li Y-H, Liu Z-H, Zeng R-H, Zeller M and Batten S R 2008 Chem. Commun. 2239; (b) Ma K, Shi Q, Hu M, Cai X and Huang S 2009 Inorg. Chim. Acta 362 4926; (c) Liu L, Ding J, Huang C, Li M, Hou H and Fan Y 2014 Cryst. Growth Des. 14 3035; (d) Tripathi S, Srirambalaji R, Singha N and Anantharaman G 2014 J. Chem. Sci. 126 1423; (e) Lina H, Lu H, Le M, Luan J, Wang X and Liu G 2015 J. Chem. Sci. 1271275

25. (a) Zhang H, Wang X, Zhang K and Teo B K 1999 Coord. Chem. Rev. 183 157; (b) Liang L, Yang C F, Ma Y Z and Deng H 2013CrystEngComm 15 365; (c) Bushuev M B, Gatilov Y V, Krivopalov V P and Shkurko O P 2015 Inorg. Chim. Acta 425182

26. (a) Special issue on Molecular materials in electronic and optoelectronic devices 1999 Acc. Chem. Res. 32 3; (b) Roundhill D M and Fackler Jr J P 2013 In Optoelectronic properties of inorganic compounds (New York: Springer Science \& Business Media)

27. (a) Balzani V, Credi A and Venturi M 2003 In Molecular Devices and Machines (Weinheim: Wiley-VCH); (b) Liao J, Blok S, Molen $\mathrm{S} \mathrm{J} \mathrm{v} \mathrm{d,} \mathrm{Diefenbach} \mathrm{S}$, Holleitner A W, Schonenberger C, Vladyka A and Calame M 2015 Chem. Soc. Rev. 44999

28. (a) Bourne S A and Mangombo Z 2004 CrystEngComm 6 438; (b) Dobrzycki L and Wozniak K 2009 J. Mol. Struct. 92118

29. (a) Satapathi S, Chattopadhyay S, Bhar K, Das S, Kumar R K, Maji T K and Ghosh B K 2011 Inorg. Chem. Commun. 14 632; (b) Khan S, Roy S, Bhar K, Ghosh R, Lin C-H, Ribas J and Ghosh B K 2013 Inorg. Chim. Acta 39840

30. Sheldrick G M 1996 SAINT, V4: Software reference manual Siemens analytical X-ray systems, Madison, WI USA

31. Sheldrick G M 1996 SADABS: Program for empirical absorption correction of area detector data, Germany: University of Gottingen

32. (a) Herbst-Irmer R and Sheldrick G M 1998 Acta Crystallogr. 54 443; (b) Gruene T, Hahn H W, Luebben A V, Meilleur F and Sheldrick G M 2014 J. Appl. Crystallogr. 47462

33. Sheldrick G M 2008 Acta Crystallogr. A64 112

34. Spek A L 2009 Acta Crystallogr. D65 148

35. Macrae C F, Edgington P R, McCabe P, Pidcock E, Shields G P, Taylor R, Towler M and van de Streek J 2006 J. Appl. Crystallogr. 39453

36. (a) Lever A B P 1984 In Inorganic electronic spectroscopy $2^{\text {nd }}$ edn. (New York: Elsevier); (b) Garcia Sole J, Bausa L E and Jaque D 2005 In An introduction to the optical spectroscopy of inorganic solids (New York: John Wiley)

37. (a) Lakowicz J R 2006 In Principles of Fluorescence Spectroscopy $3^{\text {rd }}$ edn. (US: Springer); (b) Petty M 2008 In Molecular electronics: From principles to practice (Chichester: Wiley); (c) Dutta B, Bag P, Florke U and Nag K 2005 Inorg. Chem. 44 147; (d) Chen W, Peng Q and Li Y 2008 Cryst. Growth Des. 8564 